\title{
Global Citizenship Education at a Dutch University College: Latin American Liberation Psychology informing the construction of the 'Other' and the 'Self'
}

Sabina Weistra, Eri Park, Marcin Sklad

Student of MA program, University of Oxford, Oxfordshire sabinaweistra@hotmail.com

Assistant professor of psychology, University College Roosevelt, The Netherlands e.park@ucr.nl

Associate professor of psychology, methods of social science and statistics, University College Roosevelt, The Netherlands

m.sklad@ucr.nl

\begin{abstract}
The Going Glocal project, ran at University College Roosevelt (Utrecht University) in the years 2013-2014, has the aim of providing students with more knowledge to reflect about issues of global justice in a society shaped by processes of globalisation and cosmopolitanisation, and thus an increased interconnectedness. Fifteen students attended courses on 'Global Justice and Activism in Mexico' and 'Global Citizenship', and went on a fieldtrip to Mexico during the summer. To answer the question "Did the students' self-other conceptualisation change?" two out of the ten interviews conducted between September and January 2014 at UCR were analyzed in the light of Social Identity and Social Representation Theory. The participants, who acquired knowledge about Latin American theory and encountered members of the Zapatistas movement, constructed the 'other' and approached the issues of taking responsibility and knowledge from very different perspectives, thus displaying the diversity of the impact this project had on its participants.
\end{abstract}

\section{Indexing terms/Keywords}

Global citizenship, Europe, Mexico, Others.

\section{Academic Discipline And Sub-Disciplines}

Psychology; Cultural Studies.

\section{SUBJECT CLASSIFICATION}

Social Science

\section{TYPE (METHOD/ APPROACH)}

Case study

\section{Council for Innovative Research}

Peer Review Research Publishing System

Journal: Journal of Social Sciences Research

$\mathrm{Vol}$.7, No.3

jssreditor.cir@gmail.com

www.jssronline.com 


\section{INTRODUCTION}

In present days people's positions can only be understood in global, rather than national, terms, due to increasing processes of globalization and cosmopolitanization, which promote interconnectedness across boundaries and this is why issues of global justice are becoming of concern beyond the national borders (Beck, 2002). The relationship between highand low-income countries, where people are "the subjects formed by today's colonial wound", is based more than ever on logics of neo-colonialism (Mignolo, 2005, p. 97). Regions such as Western Europe, Canada, the United States, Australia, New Zealand and Japan are at the core of the system of investment, extraction of wealth, accumulation, and reinvestment and they negotiate deals with low-income states which are severely more beneficial for their own nations (Burton \& Kagan, 2009). Anti-dumping measures constitute the most straightforward means to prevent the expansion of the Latin American market in Europe. The dumping calculations, allegedly concerned with fairness and 'levelling playing fields', are obtained by introducing different margins and the result is that imported goods with identical or even higher prices of production are listed as dumping, promoting protectionism in the name of fair competition (Lindsey \& Ikenson, 2002).

The Going Glocal project, run at University College Roosevelt (Utrecht University), has the aim of providing students with the knowledge to reflect about issues of global justice in the current multicultural society. In the framework of this initiative, the students reflected upon their social representations of the 'other', their position in the global dynamics and their identity. They familiarized with principles of Latin American theory and came back to the West with new understandings and their assumptions challenged by several encounters with, for example, people from Latin American states attempting to reach the U.S.A. at the migrants shelter, a windmill project run by a transnational company funded by, among others, a Dutch pension fund, and their encounters with visitors at the Universidad de la Tierra. ${ }^{1}$ Furthermore, in Mexico they were able to see how theory could be applied to people's everyday needs and they taught at primary and secondary schools. In the light of this, the questions this paper aims to answer are the following: did their self-other conceptualization change? If so, how?

\section{Theoretical Framework}

\section{Global Citizenship}

The field of Global Citizenship education brings together many disciplines such as philosophy, sociology, political sciences, and psychology, and constitutes a response to the raising awareness of the unequal conditions of people around the world (Andreotti, 2006). In the current situation, 1.22 billion people live with less than $\$ 1.25$ a day (World Bank, 2010). Colonialism and the perpetuation of its dynamics have led to and maintained a dichotomy between Western highincome countries and nations in the Global South. In the framework promoted by global citizenship education, all individuals, no matter their locations, are to be considered as the ultimate source of concern and as units rather than divided in families, communities or nations. People are 'units of concern' for everyone, not only for those who are similar to them. Moral cosmopolitanism refers to a political system in which all citizens have equal rights and duties whilst holding that "all persons stand in certain moral relations to one another" (Pogge, 2002, p. 176). Within moral cosmopolitanism, the interactional approach proposed by Pogge revolves around principles of ethics and assigns responsibility to avoid harming others for insignificant reasons to individuals and groups.

Western political systems are constructed around a centralisation of the power which is above citizens. However, power is to be centralised and decentralised at the same time in a situation in which people are citizens and govern themselves simultaneously (Pogge, 2002). Social justice is a fundamental feature of this discipline: individuals who can be considered to be 'global citizens' display awareness of the fact that some people live better lives at the expenses of others. The elaboration of the psychological dimensions accompanying this concept of negative duties, to avoid harming others for insignificant reasons, is developed by Park (2011), who derives three criteria for the cosmopolitan position. The individual acknowledges the violation of negative duties, thus the fact that by her/his inaction, unequal power relations are perpetuated. The experience of moral emotions such as existential guilt and anger is present; in addition, the individual feels driven to engage in socio-economic change. These are the psychological pre-requisites which would qualify an individual as adopting a global citizenship approach.

These theoretical elaborations on global citizenship found their application in an educational program of Utrecht University. The Going Glocal project, initiated at University College Roosevelt, with the support of the Dutch Ministry of Foreign Affairs, is part of critical global citizenship education. The project was divided into two phases: fifteen students attended two courses and a fieldtrip in between. The courses were designed to provide more knowledge with which to interpret the discourse on disparities between the Global North and Global South. Through teaching activities at primary and secondary schools, before and after the trip, students discussed these issues with children with the aim to spread their knowledge on colonialism and decoloniality. By doing so they became multipliers in the dissemination of the knowledge about postcolonial issues with the aim of inspiring the children. During the fieldtrip they could see examples of their theoretical knowledge and the detrimental role of Western companies and governments on the social, political and economic structures. 
The process of shaping an identity in a post-colonial society was fostered through readings from non-western scholars and teaching activities in local Dutch schools. These projects and the various initiatives in Mexico promoted the overcoming of the self-other barrier and fascinated the students who talked about the program as the practice which had been missing from their education until that point. During their stay they helped the locals with the bricklaying of a small house for the Universidad de la

Tierra and visited a migrants' shelter where people from Latin American countries stop for a couple of days before attempting to cross the border to the U.S.A.. Both encounters left a mark, as well as their confrontation with the so-called windmill project. This program, initiated in 1994 in the region of the Isthmus of Tehuantepec (Oaxaca), foresees the construction of 132 turbines for a production of 396 megawatt per year. The consequences of this plan are great and involve current and future generations. The inhabitants of the area are for the majority fishermen and because of the noise of the installation, the fish would not come close to the coast anymore, leading to severe disturbance for the environment. Adding to the disastrous consequences on the natural habitat, the locals would not see any of the green energy produced on their own land. The project is, in fact, completely in the hands of Western companies, among them the Dutch pension fund PGGM (Somos Viento, 2013).

\section{Creating the Self and Constructing the Other in the West}

Throughout this paper Social Representation Theory and Social Identity theory will be applied to explore the students' social representations of the 'other' and accordingly their positioning in the world. Social Representation Theory is helpful to understand how an individual's positioning is shaped by the influence of one's group and how social groups come into being and opposing each other. These processes are relational and comparative, meaning that people create their own identity by means of comparison to others: by being similar or different, better or worse than members of another group. Discrimination is an intellectual phenomenon which cannot be reduced to in-group/out-group dynamics, but moves well beyond that. Once the 'majority' is afraid of sharing its moral authority, it denies the humanity of the other. Prejudices are thus based on oppositions such as 'human/not human, culture/nature, domesticated/wild' (Moscovici, 2011). Once the other is defined as non-human, violence and discrimination are allowed in the mind of the oppressor. Identity is the means through which people relate to the world. It is socially and dynamically constructed and produced within the social, cultural, economic, and historical contexts by means of being intimately tied to power resources. Identities are points of identification, and as such they should not be seen as stable, but rather as a dynamic positioning process within one's historical and cultural context, concerning 'what we might become' rather than 'who we are' (Hall, 1996, p. 4).

Constructing the other and creating a self-identity are two processes which occur in a simultaneous and intertwined fashion. Especially when creating one's self-concept, desirable and undesirable characteristics are kept in mind, and the dichotomy is often reinforced exactly for the purpose of stressing what trait one should attribute to the self and to the other (Staerklé, 2013). In the West, identity is seen as a concept with boundaries, but this is only the case in as much as it is made so through power dynamics and exclusion. One's self concept is constructed by affirming what a person is not and this process results in a hierarchy: for example, defining oneself as a woman, and not a man, already implies putting one pole above the other (Hall, 1996). In the relationship between the self and the 'other', identification is a mechanism in which the object one identifies with comes to be hated and adored. The 'other' possesses characteristics that one does not like to see in the self, which are 'desirable and intimidating' (Kilomba, 2010, p. 44). These characteristics are projected through a technique which allows for distancing one's self from the 'other', namely, the split off: good characteristics and bad ones are divided within the self and the bad ones are projected on to the other. When the other is constructed, because $s /$ he is different from the norm, a hierarchy appears with it.

There are five ego defense mechanisms that the white subject, or the privileged subject, goes through in order to enter in a dialogue with the 'other': denial, guilt, shame, recognition, and reparation. Denial consists in a refusal to admit one's privileged position and it works through splitting and projection. Guilt expresses itself through rationalization and intellectualization, meaning the process of giving rational explanations when confronted with one's position; shame differs from guilt because it concerns the self-image rather than behaviors and it occurs when the western white individual starts seeing reality through the eyes of the other. During the recognition phase the person acknowledges a privileged position and attempts to repair the harm by giving up these privileges. De-constructing colonialism means becoming aware of one's own privileged position and wanting to move past the current neo-liberal situation. What happens often instead is that the awareness of sharing a responsibility for the consequences of the colonial past is put away, 'kept at a distance from the conscious' (Kilomba, 2010, p. 21). As shown by these steps, it is possible for the self and the 'other' to relate in common ground. In order to achieve this goal, the social representation of the other should be based on a 'fusion of horizon', or in other words, the highest degree of perspective-taking through which understanding is based on various contexts and perspectives coming together (Tsirogianni \& Andreouli, 2011).

\section{Latin American Liberation Psychology}

In the second half of the twentieth century, Martín-Baró proposed an approach which brought together the disciplines of sociology, anthropology, pedagogy, philosophy, and theology, as a response to the hegemonic scientific paradigm of 
mainstream social sciences and its claim to universality. Liberation psychology, meant as a way of doing psychology, constitutes an attempt to build a link between the scholarly world and everyday practice. Its origins are to be traced in Latin American countries where the dependent and neo-colonial character of their economies and severe internal inequalities have led to poverty and exclusion. Liberation is an 'ethical-critical-empowering and democratizing' process which stems from the need to resolve situations where inequalities and exclusion are present (Montero \& Sonn, 2009). It is an approach focused on the integration between cultural knowledge and the voice of the people, the oppressed minorities in particular. The point of departure of liberation is the conscientization of people. This term refers to the process of becoming aware of one's rights and duties and realizing the importance of democracy and civil society. It stands for the fact that the individual changes by transforming its own reality, by increasingly decoding the world and thus understanding the mechanisms at the base of oppression and dehumanization. In fact, liberation psychology targets exactly the institutions which perpetuate inequalities and oppression and encourage feelings of hopelessness and immobility as these constitute the status quo of Latin American people (Osorio, 2009).

Liberation psychology is set with the goal of uncovering the processes behind the problems created by abuse of power and defends the right to live with dignity. In the process of generating strategies to develop a collective consciousness, new possibilities open up in terms of self-understanding and thus present and future identity. Furthermore, this paradigm responds to a necessity of producing a science by praxis, "a practice that produces knowledge and knowledge that turns into action" (Montero \& Sonn, 2009, p.2). Praxis means working with other people to tackle problems such as the tension between the native and the 'ladinos' and between the coloured and the white population, and the struggles that generate exploitation (Osorio, 2009). This results in an infinite cycle of practicing-knowing-transforming where knowledge and transformation become intertwined: education is, in fact, not only an act of knowledge but comes with a development of the economic, social, political, ideological and historical factor. A student, therefore, is not a passive recipient of knowledge but an active agent who can bring about change. This orientation is based on a 'realismo-crítico', which opposes the usual approach of 'idealismo-metodológico', meaning that theory is important but not fundamental and that reality needs to be peeled off from its layers for its mechanisms to be understood (Burton \& Kagan, 2009). The concept of citizenship within a liberation context revolves around matters of responsibility, individual and collective, and participation. Citizenship is based on a recovery of the historical memory which will function as a tool for liberation and solidarity (Jiménez-Domínguez, 2009, p.48).

\section{Knowledge and Objectivity}

Throughout history there has been a distinction between inferior and superior knowledge, beginning with Plato who claimed that abstract ideas are nobler than experiences. Along the same lines, Spinoza asserted that reasoning lead to higher forms of knowledge whereas imagination only to a lower degree of intellect. The same distinction can be made between knowledge of the white male, constructed as a fact, and that of anybody else, considered an opinion (Kilomba, 2010). According to post-colonial theory, the white western male has constructed a system in which his knowledge is the most valued and other types of knowledge are disregarded. The discourse of minorities, such as people of colour, or women, are seen as less valid. The problem of who possesses what is considered to be 'proper' knowledge, is linked to questions of power and authority. Even basic concepts such as democracy and human rights, which in Western society are considered universal, are based on knowledge and power (Hewer, 2012). Power gives the ability to position people in specific ways, as superior or inferior, and consequently defines whose knowledge is to be valued. The concepts of 'universal reason' and of universal political, religious and social values have been defined within the Western tradition by renowned thinkers such as Descartes, Kant and Marx. Descartes' idea of 'I think, therefore I am' has ascribed to the concept of universality an eternal value which transcends time and space, and is equivalent to God's gaze on the world. Placed in its historical context, 'cogito ergo sum' should be read more as 'conquiro, ergo sum', namely, 'I conquer, therefore I am'. The philosopher claims to speak with the assumption that he knows what exists beyond time and space and that is made possible because he sees the world from the coloniser's point of view and thinks of modernity as Eurocentered (Grosfoguel, 2012).

The Zapatistas in Mexico are challenging this way of thinking which has been thriving throughout the centuries. One of the Zapatista's purposes is to counterbalance this claim to universality. Their idea of 'walking while asking questions' proposes a critical and 'epistemically diverse' dialogue which is, as a result, a de-colonialized one. The movement came into being in January 1994 in Chiapas (Mexico) under the form of a Mayan insurgency after the revolutions of the '60s and '70s against the agrarian land reforms, a time in which the majority of Mexican people had been left only with corruption, poverty, and social inequality (Holloway, 2002). The movement did not, and does not, aim at overturning the government and taking power in its hands: its members reject the 'state-centered politics' and the 'power-focused politics' which are typical of capitalist countries. The Zapatistas challenge the Western conception of politics and propose a model in which the future is uncertain and open to construction. One of their goals is to point out societal injustices and "call the attention to the faceless victims of Mexico's development, and reposition them as ethical subjects" (Popke, 2004, p. 309). During the summer of 2013 , several festivals were organized in the Zapatista's caracoles, meant to celebrate the $19^{\text {th }}$ anniversary of the uprising of the movement (Navarro, 2013). The Zapatistas celebrated the creation of their autonomous communities 
throughout Mexico and the improvements that have been taking place in the past two decades.

\section{METHODS}

The questions this paper aims to answer are: did the students' self/other conceptualization change? And if so, how? Between September 2013 and January 2014 I conducted ten interviews and transcribed eight of them. The interviewees' age ranged from 19 to 22 and the sample included two males and eight females. Two of these ten participants were chosen for this analysis. One woman, Miriam, who had never been outside of Europe before and one man, Orlando, who had been to Canada, Greenland, and the U.S.A. The content of the interviews was analyzed through content analysis, which deals with the objective and quantitative description of the manifest content, but also includes interpretations and latent content (Graneheim \& Lundman, 2003).

\section{ANALYSIS}

The trip to Mexico allowed the student to make the connection between the theoretical background they had received and the application of these notions. First of all, the project brought together knowledge from the West with Latin American theory and practice. An example is the link between the concept of 'conscientization' and the criteria of the cosmopolitan position. Conscientization stands for gradually decoding the world, but it does not only concern the cognitive aspect, but extends to emotions which are necessary to attain awareness (Montero, 2009). This knowledge is also at the base of the three criteria of the cosmopolitan position: a particular worldview with a particular emotional response and the drive to change the socio-economic status-quo (Park, 2011). For this reason, these two voices are intimately tied and strive for the same goal from the opposite side of the globe. Latin American theory and Western scholarship meet again by sharing the same perspective on the role of memory for social solidarity. A so-called 'fusion of horizons' is seen as the basis of social cohesion and solidarity. Horizons, as the values, norms and experiences that shape representations, can be expanded by focusing on the ties that already exist among people, based on shared historical contingencies (Tsirogianni \& Andreouli, 2011).

The analysis is conducted through the lenses of two main theoretical frameworks: one grounded on post-colonial whiteness theory (Kilomba, 2010; Frankenberg; 1993) and the other based on Latin American liberation psychology. The five steps discussed earlier were used for this analysis, considering that the goal of the Going Glocal project in Mexico was exactly to point out one's position and relation to others on a global level. Liberation psychology also comes into play when analysing the interviews because of its close associations with the Zapatistas' ideas. As a matter of fact, liberation psychology encourages an active attitude and a reflection about one's own framework. The two students chosen for this paper will be compared on the ground of taking or refusing responsibility towards people who do not enjoy their same privileges. Furthermore, they will be compared on the basis of the five steps of denial, guilt, shame, recognition, and reparation, and on the extent to which they are in the process of integrating alternative ways of living, such as the one suggested by Latin American liberation psychology, into their lives. In the following section it will be shown how two interviewees, Orlando and Miriam, constitute very different responses to the Going Glocal experience.

\section{Orlando}

Orlando is a 21-year old Dutch white man who had been outside of Europe three times before Mexico, having visited Greenland, Canada and the U.S.A. On the issue of responsibility and awareness of his position, Orlando represents the individual who mostly manages to keep the knowledge of a privileged position away from his consciousness (Kilomba, 2010). The following extracts display several mechanisms by which guilt is kept in check and touches upon two landmarks of the trip: the windmill project funded, among others, by a Dutch pension fund, and the visit to the migrants' shelter.

For the pension, they cannot really blame us because most of us are not really giving our pension yet or not with this firm, but probably our parents are putting money in this company that pays for the destruction of their lands. I would have found it surprising if they would have had some grudge against the group in the Netherlands, I can also imagine that this would be [the case, that] they wouldn't like it. Also with the refugee camp, there is nothing to blame, but you are leaving the place behind, they are going to America, so I can also imagine that you are in this place for two days and you are not really waiting for a group of rich foreigners who go like "this is nice, tell me your story about why you are here" (Orlando).

In terms of overcoming the gap between the self and the 'other', this extract shows a clear-cut division between an ingroup and an out-group. The in-group is constituted by the rich group from the Netherlands in opposition to the Mexicans whose land is being destroyed. This division leads to some degree of discomfort in the interviewee. Firstly, this is expressed through the denial of any involvement in the project. After the visit to the migrant shelter, Orlando says that he would have found it surprising if they had hold a grudge against him because he would leave after hearing their stories, in other words, because of his position, which is a privileged one. However, he could also imagine them feeling this grudge towards him. Orlando shows to be struggling between reviewing his position in the light of what he has been learning and 
his interest in maintaining his privileged position without feeling guilty about it. That's why he acknowledges responsibility only indirectly. From these extracts the struggle between knowing and not wanting to know appears, and the awareness of sharing a responsibility for the consequences of the colonial past is put away, 'kept at a distance from the conscious' (Kilomba, 2010, p. 21).

In the following extract it is possible to identify his tendency to project his guilt onto the other.

But people were very eager to tell their stories, maybe they thought "these people spread my story" and they could gain something from it. Even in the Zapatista place it was like people were not laughing at us. I don't think they hated us being there.

The self-other barrier is here clearly recognizable as highlighted by the expression 'these people' and the recurring opposition between 'us' and 'them'. Moreover, the mechanism of denial, which is used to legitimate violent structure of racial exclusion, is present and in this case used as a protective self-strategy. The thought that Orlando may be gaining something from the status quo is turned against the

'other' and projected. The 'other' is given the role of he who can take advantage of the situation, in a process in which 'the oppressor becomes the oppressed, and the oppressed the tyrant' (Kilomba, 2010, p. 18). It is the Mexicans who are 'exploiting' him because he will spread their story and they will profit from that. This is part of a split-off process in which the good characteristics are kept in the self-concept and the negative ones are projected onto the other and experienced as external. By doing so the white self can continue to see itself in a positive way, as embodying the virtues of morality and civilization, and thus be free of the anxiety that would come from having to accept his/her negative characteristics.

The 'other' is constructed, then, out of the imagination of the white individual and in this way the other also becomes objectified and is deprived of a voice. This mechanism becomes clear in the eyes of Orlando when, during the Zapatistas festival, he is confronted with the gaze of the other onto himself.

"I experienced in this festival, there it was clear that we were the only not Spanish speaking, most people were Spanish-speaking, when we were there really tall and blond and these people want to take pictures with you and took picture of you just sitting and then you start to realize, I don't find it very offensive cause I don't really care, but I can imagine if you have this every day, every month, every year, I can imagine that at one point you think "Oh Jesus,

I am just living my life, I am not a museum piece [...] I still had the feeling we were a bit intruders, of course it is a quite extreme word" (Orlando).

He started his comment by referring to the Zapatistas and how they must have been feeling every time a tourist stared at them and treated them as objects which they liked to photograph. This objectification is part of a historical discourse of the last decades of the nineteenth century, in which Latin America started to be considered more and more as a 'lower-class' country, not just economically but also in the general imaginary in relation to the raising discourse of white supremacy implemented in the US (Mignolo, 2005, p. 90). Latin America became part of the so-called Third World and even the Spaniards, who considered themselves 'white', were perceived as 'darker skinned'. ${ }^{3}$ From the perception of the West, 'Latin America was not 'white enough' (Mignolo, 2005, p. 90). They acquired even more characteristics of the 'other', and this is exactly what leads Orlando to react this way. He compares this situation to what it must be feeling like to be a museum piece, an object which does not have any will of its own, and is just there to be observed, deprived of a voice and the ability to contribute to a conversation. However, at this very moment he is the one who is being looked at. If the Zapatistas must be feeling like museum pieces when they are stared at, now he is turned into one because he is the one they want to take pictures of. This idea can be supported by the fact that he formulates his sentence by saying the personal pronoun ' $l$ ' rather than referring to the Zapatistas themselves. The pictures and the looks are now directed towards him, therefore, he is perceiving this uncomfortableness on himself: in the seven sentences of the extract he uses the word ' $l$ ' eight times. However, when he talks about the differences between himself and the Mexicans he uses the personal pronoun 'we' and extends the status of 'intruders' to his in-group. Feeling like an intruder with them eases his comfortableness. The students from the Netherlands all have a different appearance and do not speak Spanish, except one, and he assumes they must be feeling the same way. Having his in-group around him makes him feel that he is not the only one facing the gaze of the other onto himself.

Moreover, the comparison constitutes a paradox in and of itself: the reason why Orlando is participating to the festival in the first place is because the Zapatistas are museum pieces. They are different, they are giving hope for a different future to all those who do not want to be absorbed into the spiral of capitalism. If they had not been museum pieces, he would have never been there feeling like one himself. Orlando becomes aware of his role, namely, that of the one who does not belong there, the tourist, because other people have placed him in this position, that is, because the Mexicans stare at him and want pictures with him. This may not be the position he would have assigned to himself. The imposition of this position is the reason why he feels like an intruder. However, it is his active and personal conscious decision to join this project and visit Mexico and he is able to do so because he has the economic means to travel to the other side of the world. Orlando can take part in the festival because he is a citizen of that part of the globe against which the Zapatistas are positioning themselves. He belongs to that side of the world which has accumulated capital for centuries and still enjoys the benefit of 
colonialism.

Miriam

Miriam is a 21-year old woman from the Netherlands who had never been outside of Europe before this trip. On the matter of taking responsibility for her role and actions, she explains her position in the following quote:

"I think that I wouldn't like to work for a corporation anymore. Something that forces our, not even forces, but corporations are very powerful in the sense that they basically have the hegemony over how other people's lives are designed at the moment. So even the lives of the indigenous people are touched when a corporation does its job trying to get its logic across, trying to draw a globalized picture so then working for that seems a bit odd. Maybe I want to be a journalist but then not for a corporation or a magazine that is grounded from the Western perspective" (Miriam).

Her positioning is clearly expressed in her: she feels personally responsible for what she does and as aware of her own behavior. Her change of perspective is visible through her use of language and in particular expressions such as 'I was blind' and 'I couldn't see'. The sentence 'I was blind' is opposed to 'all the things I have heard'. Thus, her understanding has progressed and become more personal and could be attributed to witnessing in person the lifestyle of the indigenous people in Mexico, which, as she reports several times, has left a mark in her life. Later on, she also uses the expression 'I wasn't even aware that what we do in the West affects other people's lives'. There is a cognitive appraisal of how unfair the situation is and an acknowledgement of her role within the system. From her words it appears that she is also emotionally involved, as highlighted by the use of the pronoun I. This extract underlines a process of recognition of her position and whiteness and lays the basis for a reparative behavior (Kilomba, 2010). Furthermore, she talks about globalization in a way that underlines its dangers: globalizing means unifying, making everything universal. Her position against this tendency seem to echo the words of Aimé Cesaire: "My idea of the universal is that of a universal rich with all that is particular, rich with all particulars, the deepening and coexistence of all particulars" (as quoted in Grosfoguel, 2012, p. 95).

This interviewee got inspired to alter her life plans of becoming a journalist because she does not perceive herself as one helpless puppet in the system, but rather as an individual who can actively engage and change something by her actions. In support of the idea that she sees herself as an active particle of the system, she tells 'I don't waste food anymore'. This connects to the idea of reflecting upon one's framework and defying the feeling of alienation and helplessness. What is more, she rejects this idea of being a passive agent when she talks about globalization as imposed from a western perspective and she says "We don't see [negative things] as faults of the system, we see them as unlucky circumstances we are living in". She is thus opposing the passivity and acceptance of one's living conditions without questioning them. The West is, from this point of view, not so different from Mexico. People also display a fatalistic approach because they do not think they can do anything to fight against the aspects they do not like. They feel powerless in front of the system and see themselves as merely 'unlucky'. Miriam sees herself as an active agent in society who has the responsibility to do something with the knowledge she has acquired. She takes the so-called 'realismo-crítico' approach because she is trying to understand the mechanisms behind her own paralysis (Burton \& Kagan, 2009). She has become aware that her contribution matters. Miriam's emotional and cognitive engagement with the problem has led her to take action about it. Although it is not possible to change the situation, it means something to her that she tries to take action.

"That's one very tiny thing that probably in the entire economic system doesn't mean much but it definitely means something for me now, that I don't passively participate in the economic system but actively try to find a way which is healthy for both myself as for my environment as for my future generations." (Miriam)

This is an example of praxis inspired by knowledge, the cycle of practicing-knowing-transforming (Osorio, 2009). The awareness that the economic system is unfair towards people that do not live in the West leads her to transform her reality and identity and enlarge her regard to a broader group of people. Practice and knowledge are informing each other (Montero \& Sonn, 2009). Moreover, in this extract it becomes clear how different types of knowledge come together, the practical and the theoretical one (Jímenez-Domínguez, 2009). Throughout the interview it has become clear how Miriam is trying to integrate her experience in Mexico and her privileged position in the West to which she has now returned. This integration process is not always easy.

"I am also here going to parties and I just spend my money like carelessly to have fun times. So it's not as if, it's in a way a very selfish decision but of course it's always, it's very double, everything is double, that's, I feel conflicted a bit after the course because it opened viewpoints that I didn't even know were there." (Miriam)

Two logics are opposing each other. She knows that some people do not have enough money to buy food and that she has enough to go to parties, which leads to a double feeling, an acceptance and rejection of her knowledge. She tries to resolve this conflict by saying 'I wasn't raised in that logic, so I will still be selfish in the core somewhere'. Miriam has reached the recognition phase but is unsure whether she will engage completely in the last one, namely, reparation, or the process of giving up her privileged position. In general, it is a matter of positioning herself in respect to her new knowledge (Kilomba, 2010). It is not only hard to reconcile two different logics but also deciding whether she is willing to give up her 
privileges. It is remarkable, however, the degree of self-awareness she displays, to the point of saying that now "instead of only seeing the master program, I now see other ways of living and I need to decide what I want to do with that knowledge. And it's hard".

\section{CONCLUSION}

Miriam's and Orlando's interviews were chosen for this analysis because these participants position themselves very differently in relation to the Going Glocal experience and they make clear the diversity of impact this project can have. In terms of how the 'other' was constructed and how their self-concept changed, Orlando constructs the 'other' as an object rather than a subject, projecting onto him what he does not want to see in himself. He is struggling with acknowledging his privileged position and does not see a link between the fact that he is a man from the West and the ability to take this trip or between the Dutch pension company contributing to the wind-mill project and his family potentially giving money to the fund. On the other hand, Miriam is aware of possessing the power of changing the status quo in the sense that she can contribute to how society shapes hers and other people's lives, in a way that seems deeply inspired by Latin American theory and her encounter with members of the Zapastista movement. This becomes apparent when she tells about considering giving up her dream to become a journalist because of the consequences it might have on others. Even concerning everyday issues, such as not wasting food, Miriam emphasized that it matters to her that she at least tries.

In conclusion, for the participating students the Going Glocal project certainly contributed in raising awareness on issues of global justice and allowed them to look beyond their national boundaries and customs. The extracts presented in this paper show how the interviewees were busy re-thinking their values and developing a critical approach on knowledge in the light of their insights into Latin American liberation theory and the Zapatistas encounter. Their sense of empowerment was further enhanced thanks to their role as multipliers in the dissemination of the knowledge about post-colonial issues. Through teaching, they not only inspired the children, but they also got inspired themselves to take initiative in their own society. The challenge the students were faced with, the main one being to re-evaluate their construction of the 'other', led to a revision of their own self-concept. Notwithstanding individual differences in the way the project was approached, it is safe to conclude that none of these processes about the overcoming of the self-other barrier would have been possible without the Going Glocal.

\section{ACKNOWLEDGMENTS}

This research is supported by a grant from 'Subsidies for Citizenship and Development Cooperation' (SBOS), a program of the Dutch Ministry of Foreign Affairs. Special thanks to Dr. Rolando Vasquez, Prof. Barbara Oomen, Dr. John Friedman, Dr. Fatima Mueller-Friedman, Vicki Haverkate and Anneke Oss.

\section{REFERENCES}

[1] Andreotti, V. (2006). Soft versus critical global citizenship education. Policy \& Practice -A Development Education Review, 3, 40-51.

[2] Beck, U. (2002). The Cosmopolitan Society and its enemies. Theory Culture Society, 19 (1-2), 17-44.

[3] Burton, M., \& Kagan, C. (2009). Towards a Really Social Psychology: Liberation Psychology Beyond Latin America. In In M. Montero \& C. Sonn (Eds.), Psychology of Liberation (pp. 51-72). New York City: Springer.

[4] Davis, L. (2006). Global citizenship: abstraction or framework for action? Educational Review, 58(1), 5-25.

[5] Epley, N., \& Caruso, E. M. (2004). Egocentric Ethics. Social Justice Research, 17(2), 171-187.

[6] Frankenberg, R. (1993). White Women, Race Matters: The Social Construction of Whiteness. Minneapolis: University of Minnesota Press.

[7] Graneheim, U.H., \& Lundman, B. (2003). Qualitative content analysis in nursing research: concepts, procedures and measures to achieve trustworthiness. Nurse Education Today, 24, 105-112.

[8] Grosfoguel, R. (2012). Decolonizing Western Universalisms: Decolonial Pluriversalism from Aimé Césaire to the Zapatistas. Transmodernity: Journal of Peripheral Cultural Production of the Luso-Hispanic World, 1(3), 87-104.

[9] Hall, S. (1996). Who needs ‘Identity’?. In S, Hall \& P., Du Gay (Eds.), Questions of Cultural Identity. (pp. 1-18). London: Sage Publications.

[10] Hewer, C. J. (2012). Tracing the Social Dynamics of Peace and Conflict. Papers on Social Representations, 21 , 1-22.

[11] Holloway, J. (2002). Zapatismo and the Social Sciences. Capital \& Class, 26, 153-160.

[12] Jiménez-Domínguez, B. (2009). Ignacio Martín-Baro's Social Psychology of Liberation: Situated Knowledge and Critical Commitment against Objectivism. In M. Montero \& C. Sonn (Eds.), Psychology of Liberation (pp. 37-50). New York: Springer.

[13] Kilomba, G. (2010). Plantation Memory. Episodes of Everyday Racism. Unrast Verlag: Munster. Lindsey, B., \& Ikenson, D. (2002). Antidumping 101: The Devilish Details of "Unfair Trade" Law.

Trade Policy Analysis, 20. Retrieved from: < http://www.cato.org/publications/trade-policy analysis/antidumping-101devilish-details-unfair-trade-law?print> 
[14] Mignolo, W. D. (2005). The Idea of Latin America. Blackwell Publishing: Oxford.

[15] Montero, M., \& Sonn, C. (2009). Psychology of Liberation: Theory and Applications. New York City: Springer.

[16] Montero, M. (2009). Methods for Liberation: Critical Consciousness in Action. In In M. Montero \& C. Sonn (Eds.), Psychology of Liberation (pp. 73-91). New York City: Springer.

[17] Moscovici, S. (2011). An essay on social representations and ethnic minorities. Social Science Information, 50(3-4), $442-461$.

[18] Navarro, C. (2013). Ejército Zapatista de Liberación Nacional Observes 19th Anniversary of Uprising in Chiapas. SourceMex, Latin America Data Base.

[19] Osorio, J. M. F. (2009). Praxis and Liberation in the Context of Latin American Theory. In In M. Montero \& C. Sonn (Eds.), Psychology of Liberation (pp. 11-36). New York: Springer.

[20] Park, E. (2011). Social Solidarity in a Transnational Setting: The Cosmopolitan Position. Papers on Social Representations, 20, 6.1-6.19.

[21] Pogge, T. W. (2002). World Poverty and Human Rights. Cambridge: Polity Press.

[22] Popke, J. E. (2004). The face of the other: Zapatismo, responsibility and the ethics of deconstruction. Social \& Cultural Geography, 5(2), 301-317.

[23] Que es Unitierra?. (2014). Universidad de la Tierra en Oaxaca. [web log]. Retrieved May, 2014 from http://unitierra.blogspot.com.br/

[24] Staerklé, C. (2013). The True Citizen: Social Order and Intergroup Antagonisms in Political Lay Thinking. Papers on Social Representations, 22, 1.1-1.21.

[25] Somos Viento (2013). Retrieved from https://www.youtube.com/watch?v=1YRolVuXInI\#t=86

[26] Tsirogianni, S., \& Andreouli, E. (2011). Beyond Social Cohesion: The Role of 'Fusion of horizons' in Inter-group Solidarities. Papers on Social Representations, 20, 5.1-5.25.

[27] World Bank (2010). World Development Report 2010. New York: Oxford University Press.

\section{Author' biography}

Sabina Weistra received her BA in Social Sciences from University College Roosevelt, Utrecht University and does her MA at the University of Oxford.

Dr. Eri Park works as an Assistant Professor in Psychology at UCR. She received her Ph.D. from the Institute of Social Psychology at The London School of Economics and Political Science. Her interests lie in Global Citizenship Education and Global Justice Research.

Dr. Marcin Sklad, an associate professor of psychology, methods of social sciences and statistics at University College Roosevelt (Utrecht University). His current research focuses on two areas: a) programs enhancing the pedagogical function of education and citizenship education, b) applied cognitive psychology. He completed his Ph.D. in Social Cognitive Psychology at Warsaw University. 